\title{
REPORT
}

\section{Effects of Selenium Enriched Reperfusion Solutions on Isolated Guinea Pig Hearts}

\author{
Volkan Sinci, Serdar Gunaydin, Sedat Kalaycioglu, Halim Soncul, Levent Gokgoz and Eser $\mathbf{O z}^{1}$ \\ Department of Cardiovascular Surgery and ${ }^{1}$ Physiology, Gazi University, School of Medicine, Ankara, Turkey
}

(Received for publication on April 30, 1998)

\begin{abstract}
A comparative study on isolated guinea pig hearts was carried out to determine the role of selenium enriched reperfusion solutions on postischemic reperfusion injury. The hearts of 20 control and 20 study group guinea pigs were mounted on a Langendorff perfusion apparatus and were perfused by gassed Krebs-Henseleit solution at $37^{\circ} \mathrm{C}$. The hearts were then arrested by discontinuing the KrebsHenseleit perfusion. After 20 minutes of normothermic ischemia, in the study group, the hearts were reperfused by selenium enriched Krebs-Henseleit solution $\left(10^{-3} \mathrm{mMol} / \mathrm{L}\right)$ and in the control group only Krebs-Henseleit solution was used. Postischemic percentage recovery of mechanical cardiac functions (heart rate and contractile force) and postischemic tissue degeneration indicators Malondialdehyde (MDA) and Adenosine deaminase (ADA) were compared between the groups. Mean percentage change of heart rate, contractile force and heart work were significantly higher $(\mathbf{p} \leqq \mathbf{0 . 0 0 0 1})$ and tissue MDA and ADA levels were lower $(p \leqq 0.001)$ in the selenium reperfused group. Our results demonstrated that addition of selenium to reperfusion solutions significantly improved cardiac functional recovery and decreased postischemic myocardial injury. (Keio J Med 47 (4): 219-222, December 1998)
\end{abstract}

Key words: selenium, free oxygen radicals, reperfusion injury

\section{Introduction}

There has been a renewal of interest in the protective role of selenium in cardiovascular disorders, inspired by experimental evidence that this trace element could modulate leukotriene and prostoglandin synthesis in both endothelial cells and platelets. Selenium, as an essential part of glutathione peroxidase takes part in the reduction of hydrogen peroxides and lipid peroxides. ${ }^{1}$

Several epidemiological, clinical and experimental studies support the concept that selenium and other antioxidants have roles in the development of human cardiovascular diseases. ${ }^{2-3}$ Selenium deficiency has been shown to be associated with cardiomyopathy and other cardiovascular diseases in both animals ${ }^{4,5}$ and humans. ${ }^{6}$

There is still intensive interest in different reperfusion solutions, techniques and reperfusion additives for better myocardial recovery during cardiac operations.
Several studies have demonstrated that myocardial recovery with reperfusion solutions can be improved by adding agents to inhibit oxyradical production or to degrade the reactive species. ${ }^{7,8}$

In this study, we had a goal to search the effect of selenium enriched reperfusion solutions on postischemic cardiac recovery.

\section{Materials and Methods}

\section{Animals and reperfusion techniques}

Hearts were obtained from male guinea pigs $(\mathrm{N}=20$ for control and $\mathrm{N}=20$ for the study group) weighing 300-430 grams. All animals received human care in compliance with the "Principles of Laboratory Animal Care" formulated by the National Society for Medical Research and the "Guide for the Care and Use of Laboratory Animals" prepared by the Institute of Laboratory Animal Resources and published by the 
National Institutes of Health (NIH Publication No. 86-23, revised 1985). University Research Ethics Committee approval was also obtained.

The animals were anesthetized by thiopental $20 \mathrm{mg} /$ $\mathrm{kg}$ and given 200 units of heparin into the femoral vein. The hearts (1.8-2.5 gr.) were rapidly removed and cannulated via the aortic root. The hearts were then mounted on a modified Langendorff perfusion apparatus and perfused by a gassed (oxygen 95\%, carbondioxide $5 \%$ ) Krebs-Henseleit solution at a rate of 10 $\mathrm{ml} / \mathrm{min}$. at $37^{\circ} \mathrm{C}$. The composition of the solution was $\mathrm{NaHCO}_{3}: 25 \mathrm{mMol} / \mathrm{L}, \mathrm{NaCl}: 118 \mathrm{mMol} / \mathrm{L}, \mathrm{KH}_{2} \mathrm{PO}_{4}$ : $1.2 \mathrm{mMol} / \mathrm{L}, \mathrm{KCl}: 4.8 \mathrm{mMol} / \mathrm{L}, \mathrm{MgSO}_{4}: 1.2 \mathrm{mMol} / \mathrm{L}$, $\mathrm{CaCl}_{2}: 1.2 \mathrm{mMol} / \mathrm{L}$ and glucose : $11.1 \mathrm{mMol} / \mathrm{L}$.

\section{Protocol}

The contractile force ( $\mathrm{mm} / \mathrm{gr}$ ) and heart rate (beat/ minute) were recorded following the duration of 20 min. for a stabilization period under Krebs-Henseleit perfusion. The hearts were then arrested by discontinuing the Krebs-Henseleit perfusion. During the ischemic period the hearts were kept at normothermic conditions.

After 20 minutes of ischemia, the reperfusion was started by the same buffer at $37^{\circ} \mathrm{C}$ in the control group and by the Na selenite $\left(10^{-3} \mathrm{mMol} / \mathrm{L}\right)$ enriched KrebsHenseleit solution in the study group. The ventricular contractile force and heart rate were recorded again at the $20^{\text {th }}$ minute of reperfusion.

Afterwards, the hearts were placed into the liquid nitrogen tank $\left(-140^{\circ} \mathrm{C}\right)$. Malondialdehyde (MDA) (an indicator for lipid peroxidation) and Adenosine deaminase (ADA) (an index of ATP degradation) levels were measured for determination of the tissue degeneration in both groups.

\section{Calculations}

The following calculations were made.

Percentage recovery of heart rate

$$
=\frac{\text { Postischemic heart rate } \times 100}{\text { Preischemic heart rate }}
$$

Percentage recovery of contractile force

$$
=\frac{\text { Postischemic contractile force } \times 100}{\text { Preischemic contractile force }}
$$

Percentage recovery of heart work

$$
=\frac{\text { Postisch. heart rate } \times \text { postisch. cont. } \times 100}{\text { Preisch. heart rate } \times \text { preisch. contractions }}
$$

\section{Data and statistics}

Ventricular contractile force $(\mathrm{mm} / \mathrm{gr})$ and heart rate (beat/min.) were recorded through isometric force transducer (UGO Basile 7004), (a resting tension of $5 \mathrm{gm}$. was applied) connected to a (UGO Basile 7050 microdynomometer).

Tissue MDA levels were measured by thiobarbituric acid technique ${ }^{9}$ and for ADA levels Lowry Method was used. ${ }^{10}$

The results were presented as mean and standard error of the mean. Overall significance of differences between groups was determined by "t test" using "Microsoft Excel 6.0" PC program.

\section{Results}

In the control group, the mean percentage change of the heart rate was $72.4 \pm 9 \%$ of the baseline, the mean percentage recovery of ventricular contractile force was $66.2 \pm 7 \%$ and the percentage recovery of the heart work was $45.2 \pm 9 \%$.

In the study group, however, the mean percentage recovery of heart rate was $100.3 \pm 8 \%$, mean percentage recovery of contractile force was $114.3 \pm 7 \%$ and percentage recovery of heart work was $115.2 \pm 8 \%$.

Statistically speaking, as it can easily be noticed, there are significant differences between two groups in respect of heart rate ( $p \leqq 0.001)$, ventricular contractile force $(p \leqq 0.0001)$ and percentage recovery of heart work ( $\mathrm{p} \leqq 0.0001$ ) (Fig. 1). In the control group, the RIA measurements in the preserved hearts revealed

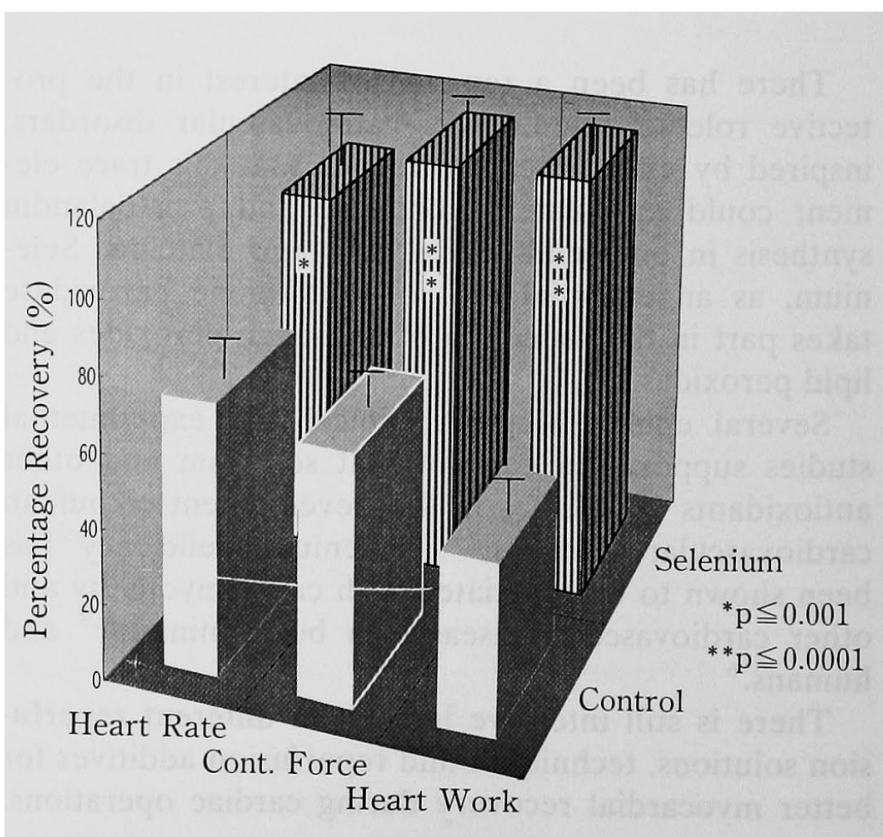

Fig. 1 Hemodynamic parameters of control and selenium groups. 
that the mean concentration of ADA was $11.8 \pm$ $1.3 \mathrm{nmol} / \mathrm{min} / \mathrm{mg}$ prot. and the mean concentration of MDA was $0.046 \pm 0.007 \mathrm{nmol} \mathrm{MDA/g}$ tissue.

In the study group, the RIA measurements in the preserved hearts demonstrated that the mean concentration of ADA was $8.7 \pm 1.1 \mathrm{nmol} / \mathrm{min} / \mathrm{mg}$ prot. and the mean concentration of $\mathrm{MDA}$ was $0.027 \pm 0.003$ $\mathrm{nmol} \mathrm{MDA} / \mathrm{g}$ tissue. From a statistical point of view, tissue MDA and ADA levels were significantly lower in the selenium group $(p \leqq 0.001)$ (Figs. $2 a, b)$.

\section{Discussion}

In experimental as well as clinical studies, antioxidant trials have often been undertaken to prevent antioxidative stress, however oxygen derived free radicals have been currently suspected to be widely involved in the aetiology of several clinical disorders. ${ }^{11}$

Early reperfusion after myocardial infarction improves survival rate and is thought to preserve myo-

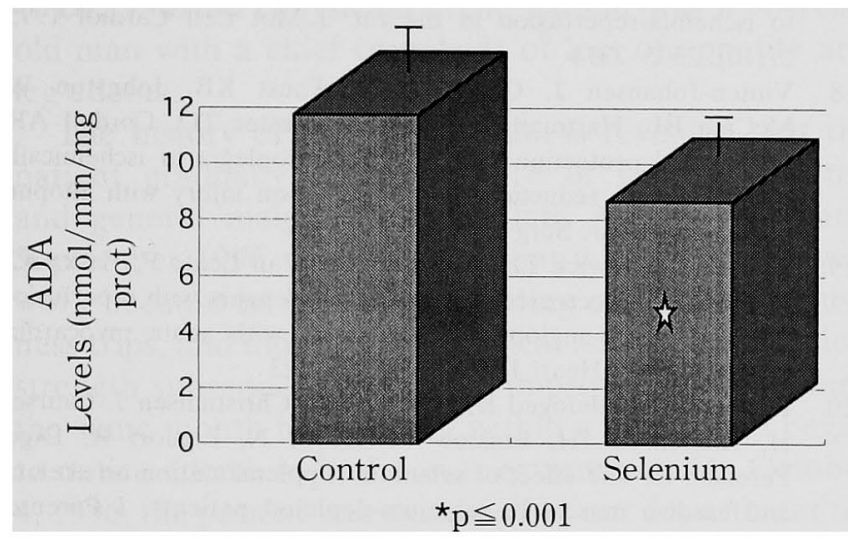

Fig. 2a Adenosine deaminase (ADA) levels in two groups.

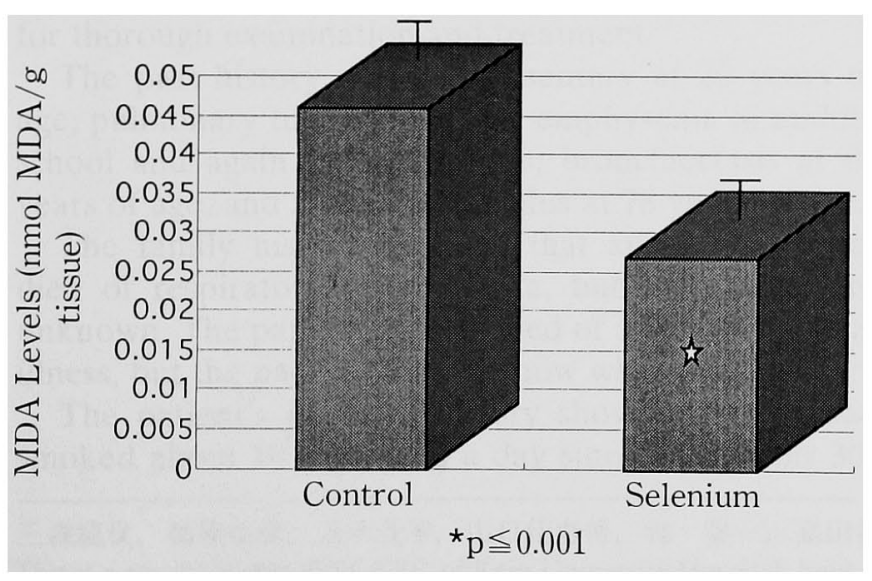

Fig. 2b Malondialdehyde (MDA) levels in two groups. cardial function, but the reperfusion of the ischemic tissue may release oxygen free radicals which could adversely affect left ventricular function and diminish the beneficial effects of reperfusion. These ideas led us to search for an effective agent to be used in the reperfusion solutions to overcome the negative effects of oxygen free radicals. We have studied the effects of selenium on isolated guinea pig lungs before ${ }^{12}$ and a similar technique was used in our early selenium cardioplegia study to observe the effects during the ischemic period. ${ }^{13}$ As a complementary study, we concentrated on selenium reperfusion to study the effects on possible prevention of the reperfusion injury.

Because selenium is a constituent of glutathione peroxidase, ${ }^{14}$ an enzyme which protects the cells from damage due to organic peroxides, especially in tissues that function in highly aerobic conditions. ${ }^{15}$

Therefore, selenium is part of a system that provides a means of defense against the accumulation of lipid peroxides and free radicals that damage cell membranes and macromolecules including DNA. ${ }^{16}$ Glutathione peroxidase may also influence prostaglandin and leukotriene metabolism in platelets and in other tissues. ${ }^{5}$

Pucheu et al. demonstrated the protective effects of selenium in limiting ischemia-reperfusion injury and suggested a possible use in the field of anti-ischemic therapy. ${ }^{17}$

We have also preferred to use normothermic ischemia since we believe that postischemic reperfusion damage after global ischemia can be avoided or minimized by substituting some brief warm reperfusion solutions during the initial phase of reoxygenation. ${ }^{18}$

Our results demonstrated the protective effects of selenium in the postischemic reperfusion injury in mechanical parameters by its anti-oxidative effects as well as tissue protection indicators, experimentally. In the clinical sense, there are also many clues for the indication of selenium. Lafont et al. studied 10 patients undergoing coronary angioplasty within 4 hours of myocardial infarction to measure the impact of abrupt reperfusion on free radical scavenger related indexes. They demonstrated the decrease in plasma alpha-tocopherol and selenium after reperfusion in this group of patients and concluded that this data may reflect the general alteration in plasma free radical scavenger levels, suggesting consumption of plasma free radical scavengers with reperfusion after acute myocardial infarction. ${ }^{19}$

Selenium has also been used in the therapy of cardiomyopathies and effects on cardiac and skeletal muscle have been studied. Results were promising and the only side effect was demonstrated to be increase of the mean diameter of muscle fiber type $1 .^{20}$

Our data supports the evidence of selenium as a free 
radical scavenger, that may be a useful protective agent in the postischemia period. However, further studies, especially the effects under extracorporeal circulation and within cardioplegic solutions, should be searched in details.

\section{References}

1. Vitoux D, Chappuis $\mathbf{P}$, Arnaud J, Bost $\mathbf{M}$, Accominotti $\mathbf{M}$, Roussel AM: Selenium, glutathione peroxidase, peroxides and platelet functions. Ann Biol Clin 1996; 54: 181-187

2. Salonen JT, Salonen R, Seppanen K, Kantola M, Parviainen M, Alfthan G, Maenpaa PH, Taskinen E, Rauramaa R: Relationship of serum selenium and antioxidants to plasma lipoproteins, platelet aggregability and prevalent ischemic heart disease in Eastern Finnish men. Atherosclerosis 1988; 70: 155-160

3. Oster O, Dahm M, Oelert H: Element concentrations (selenium, copper, zinc, iron, magnesium, potassium, phosphorous) in heart tissue of patients with coronary heart disease correlated with physiological parameters of the heart. Eur Heart J 1993; 14: 770774

4. Chen H, Tappel AL: Protection of heme proteins by vitamin E, selenium, and beta-carotene against oxidative damage in rat heart, kidney, lung and spleen. Free Radic Res Commun 1993; 19: $183-190$

5. Zhu Z, Kimura M, Itokawa Y: Effect of selenium and protein deficiency on selenium and glutathione peroxidase in rats. Biol Trace Elem Res 1993; 36: 15-23

6. Korpela H, Kumpulainen J, Jussila E, Kemila S, Kaariainen M, Kaariainen T, Sotaniemi EA: Effect of selenium supplementation after acute myocardial infarction. Res Commun Chem Pathol Pharmacol 1989; 65: 249-252

7. Coudray C, Boucher F, Richard MJ, Arnaud J, De Leiris J, Favier A: Zinc deficiency, ethanol and myocardial ischemia affect lipoperoxidation in rats. Biol Trace Elem Res 1991; 30: 103-118

8. Rosenkranz ER, Buckberg GD: Myocardial protection during surgical coronary reperfusion. J Am Coll Cardiol 1983; 1: 12351246

9. Mihara M, Uchiyama M: Determination of malonaldehyde pre- cursor in tissues by thiobarbituric acid test. Anal Biochem 1978; 86: 271-278

10. Lowry OH, Rosenbrough NJ, Ferr AL, Randall RJ: Protein measurement with the folin fenol reagent. J Biol Chem 1951; 44: 193-263

11. Coudray C, Hida H, Boucher F, Tirard V, de Leiris J, Favier A: Effect of selenium supplementation on biological constants and antioxidant status in rats. J Trace Elem Med Biol 1996; 10: 12-19

12. Erbas D, Soncul H, Turkozkan N, Aricioglu A, Muftugoglu S, Ersoz A: Effect of selenium on ischemic and reperfusion injury in isolated guinea pig lungs. Gen Pharmacol 1995; 26: 1669-1672

13. Soncul H, Tatlican O, Halit V, Oz E, Sinci V, Salman E, Gokgoz L, Turkozkan N, Ersoz A: The effect of selenium added cardioplegia in guinea pigs. Gen Pharmacol 1994; 25: 1493-1497

14. Oster O, Drexler M, Schenk J, Meinertz T, Kasper W, Schuster CJ, Prellwitz W: The serum selenium concentration of patients with acute myocardial infarction. Ann Clin Res 1986; 18: 36-42

15. Padmaja K, Somasekharaiah BV, Prasad AR: Selenium induced lipid peroxidation in heart tissue of chick embryos. Bull Environ Contam Toxicol 1993; 51: 401-408

16. Sunde RA, Dyer JA, Moran TV, Evenson JK, Sugimoto M: Phospholipid hydroperoxide glutathione peroxidase: full-length pig blastocysts cDNA sequence and regulation by selenium status. Biochem Biophys Res Commun 1993; 193: 905-911

17. Pucheu S, Coudray C, Tresallet N, Favier A, de Leiris J: Effect of dietary antioxidant trace element supply on cardiac tolerance to ischemia-reperfusion in the rat: J Mol Cell Cardiol 1995; 27(10): 2303-2314

18. Vinten-Johansen J, Chiantella V, Faust KB, Johnston W, McCain BL, Hartman M, Mills SA, Hester TO, Cordell AR: Myocardial protection with blood cardioplegia in ischemically injured hearts: reduction of reoxygenation injury with allopurinol. Ann Thorac Surg 1988; 45: 319-326

19. Lafont A, Marwick TH, Chisolm GM, Van Lente F, Vaska KJ, Whitlow PL: Decreased free radical scavengers with reperfusion after coronary angioplasty in patients with acute myocardial infarction. Am Heart J 199,6; 131: 219-223

20. Rannem T, Ladefoged K, Hylander E, Christiansen J, Laursen $\mathrm{H}$, Kristensen JH, Linstow M, Beyer $\mathrm{N}$, Liguori R, DigePetersen $\mathrm{H}$ : The effect of selenium supplementation on skeletal and cardiac muscle in selenium-depleted patients. J Parenter Enteral Nutr 1995; 19: 351-355 